\title{
Renin Expression in Renal Proximal Tubule
}

Orson W. Moe, * Kazutomo Ujiie, Robert A. Star, R. Tyler Miller, Jeffrey Widell, Robert J. Alpern, and William L. Henrich

Department of Internal Medicine, University of Texas Southwestern, and *Veterans Affairs Medical Centers, Dallas, Texas 75230

\begin{abstract}
Angiotensinogen, angiotensin-converting enzyme, and renin constitute the components of the renin-angiotensin system. The mammalian renal proximal tubule contains angiotensinogen, angiotensin-converting enzyme, and angiotensin receptors. Previous immunohistochemical studies describing the presence of renin in the proximal tubule could not distinguish synthesized renin from renin trapped from the glomerular filtrate. In the present study, we examined the presence of renin activity and mRNA in rabbit proximal tubule cells in primary culture and renin mRNA in microdissected proximal tubules. Renin activity was present in lysates of proximal tubule cells in primary culture. Cellular renin content in cultured proximal tubule cells was increased by incubation with $10^{-5} \mathrm{M}$ isoproterenol and $10^{-5} \mathrm{M}$ forskolin by 150 and $110 \%$, respectively. In addition, renin transcripts were $\operatorname{detected}$ in $\operatorname{poly}(A)^{+}$RNA from cultured proximal tubule cells by RNA blots under high stringency conditions. In microdissected tubules from normal rats, renin mRNA was not detectable with reverse transcription and polymerase chain reaction. However, in tubules from rats administered the angiotensinogen-converting-enzyme inhibitor, enalapril, renin was easily detected in the $S 2$ segment of the proximal tubule. We postulate the existence of a local reninangiotensin system that enables the proximal tubule to generate angiotensin II, thereby providing an autocrine system that could locally modulate $\mathrm{NaHCO}_{3}$ and $\mathrm{NaCl}$ absorption. (J. Clin. Invest. 1993. 91:774-779.) Key words: proximal tubule • renin $\cdot \mathrm{mRNA} \cdot$ beta-adrenergic agonist $\bullet$ angiotensin-converting enzyme inhibition
\end{abstract}

\section{Introduction}

Angiotensin II (AII) ${ }^{1}$ is an important regulator of proximal tubule $\mathrm{NaCl}$ and $\mathrm{NaHCO}_{3}$ absorption $(1,2)$. Although this effect is partially hemodynamic in nature, AII also has direct effects on the proximal tubule epithelium (3-6) that are mediated by AII receptors on both the apical and basolateral

Portions of this work have been presented in abstract form in the American Society of Nephrology meeting in Washington DC in December 1990.

Dr. Widell's present address is Pulmonary and Critical Care Division, Medical College of Wisconsin, 9200 W. Wisconsin Ave., Milwaukee, WI 53226.

Address reprint requests to Dr. Orson W. Moe, Department of Internal Medicine, University of Texas Southwestern Medical Center, 5323 Harry Hines Blvd., Dallas, TX 75230-8856.

Received for publication 3 February 1992 and in revised form 31 July 1992.

1. Abbreviations used in this paper: $\mathrm{AI}$, angiotensin I; AII, angiotensin II; JG cells, juxtaglomerular cells; RT-PCR, reverse transcriptionpolymerase chain reaction.

The Journal of Clinical Investigation, Inc.

Volume 91, March 1993, 774-779 membranes (7-9). Recent studies have suggested that AII may be produced by the proximal tubule (10); if this were the case, the potential would exist for an autocrine regulatory system in the proximal tubule.

In this regard, several components of the renin-angiotensin system are known to be present in proximal tubule cells. Angiotensinogen protein and mRNA are present in the proximal tubule (11-13), and angiotensin-converting-enzyme activity is abundant in the apical brush border (14-18). The missing component of a complete renin-angiotensin system is renin. In theory, renin synthesized by juxtaglomerular cells (JG cells) could be delivered to the proximal tubule via peritubular capillaries or glomerular filtration. In addition, if proximal tubule cells were to synthesize renin, this epithelium would possess all three components of the renin-angiotensin system.

Although renin has been found in subapical vesicles of proximal tubule cells by immunohistochemistry $(18,19)$, in situ hybridization studies have not been able to demonstrate renin transcripts in these cells (19-21). Since proximal tubule cells are endocytotically active, one interpretation of the above findings is that renin delivered to the proximal tubule via glomerular filtration is endocytosed. To circumvent thi: problem, we examined proximal tubule cells in primary culture for renin activity and mRNA and microdissected proximal tubules for renin mRNA. The present studies demonstrate the presence of renin mRNA and regulated synthesis of renin in proximal tubule cells in culture and regulated expression of renin mRNA in the microdissected rat $\mathrm{S} 2$ proximal tubule. These studies provide evidence for a complete renin-angiotensin system in the proximal tubule.

\section{Methods}

Cell culture. Renal proximal tubule cells were grown in primary culture as previously described (22). Briefly, 4-6-wk-old male New Zealand rabbits were killed by decapitation and cortical sections were digested with $0.1 \%$ collagenase, centrifuged through an isosmotic 50\% Percoll gradient, and proximal tubules were recovered from the F4 fraction as described by Vinay et al. (23). Tubules were inoculated and cultured in 1:1 DME/Ham's F12, supplemented with $5 \mu \mathrm{g} / \mathrm{ml}$ insulin, $50 \mathrm{nM}$ hydrocortisone, $35 \mu \mathrm{g} / \mathrm{ml}$ transferrin, $29 \mathrm{nM}$ sodium selenite, $20 \mu \mathrm{M}$ ethanolamine, $1.5 \mathrm{mM}$ glutamine, $100 \mathrm{U} / \mathrm{ml}$ penicillin, and $100 \mu \mathrm{g} /$ $\mathrm{ml}$ streptomycin. For the first $3 \mathrm{~d}$ of culture, 3\% FBS was added to the medium. Medium was changed on alternate days after the first $3 \mathrm{~d}$ until the cells reached confluence in $2 \mathrm{wk}$, and insulin and hydrocortisone were removed for $2 \mathrm{~d}$ before study.

Renin release and content. Renin activity was assayed in triplicate as the rate of generation of angiotensin I (AI) from angiotensinogen by the antibody-trapping method of Poulsen and Jorgensen as previously described $(24,25)$. Renin secretion was defined as renin activity in the supernatant of either cultured proximal tubule cells or isolated glomeruli. In these studies, prewarmed RPMI was added to either confluent proximal tubule monolayers or 15-20 microdissected glomeruli for $6 \mathrm{~h}$ and retrieved for renin activity assay. For studies with agonists in proximal tubule cells, $10^{-5} \mathrm{M}$ isoproterenol or $10^{-5} \mathrm{M}$ forskolin was added to the incubation medium. Cellular renin content was defined as renin 
activity in the cell lysate after removal of the medium. In these studies, proximal tubule cells were pretreated with either control medium or medium containing $10^{-5} \mathrm{M}$ isoproterenol or $10^{-5} \mathrm{M}$ forskolin for $6 \mathrm{~h}$, washed with buffered saline, and then lysed by addition of distilled water. Renin content in microdissected glomeruli was measured similarly as renin activity after hypotonic lysis of glomeruli. For inhibitor studies, isoproterenol-treated proximal tubule cells were assayed for renin in the absence and presence of $10^{-5} \mathrm{M}$ of the nonpeptide renin inhibitor A-74273 (generously provided by Dr. Hollis Kleinert, Abbott Laboratories, Abbott Park, IL). Both renin secretion and cell content are expressed as $\mathrm{ng} \mathrm{AI}$ generated $/ \mathrm{h}$ per $\mathrm{mg}$ of cellular protein as determined by the method of Lowry et al. (26). Differences in means were assessed by the Scheffe two-way analysis of variance (27) or Student's $t$ test as appropriate.

RNA blots. Total cellular RNA was isolated as previously described (28). Cells were homogenized in guanidium thiocyanate, centrifuged through a $\mathrm{CsCl}$ cushion, and further purified with phenol-chloroform extraction and ethanol precipitation. The resultant RNA was poly(A) selected by oligo-dT chromatography, size-fractionated by formaldehyde agarose gel electrophoresis, and transferred to nylon membranes. For DNA probe synthesis, rat renin cDNA (a gift from Dr. Kevin R. Lynch, University of Virginia School of Medicine, Charlottsville, VA) (29) was subcloned into bacteriophage M13 and single-stranded sense DNA templates were prepared for synthesis of uniformly ${ }^{32} \mathrm{P}$-labeled $\left(\sim 10^{9} \mathrm{cpm} / \mu \mathrm{g}\right.$ probe $)$ antisense single-stranded renin $\mathrm{cDNA}$ probes as previously described (28). Membranes were hybridized under high stringency conditions ( $50 \%$ formamide; $5 \times$ SSC; $5 \times$ Denhardt's; $1 \%$ SDS; $42^{\circ} \mathrm{C} ; 3-4 \times 10^{7} \mathrm{cpm}$ probe $)$ and washed $(2 \times \mathrm{SSC}, 0.1 \%$ SDS, $22^{\circ} \mathrm{C} \times 15 \mathrm{~min}$, and then $0.1 \times \mathrm{SSC}, 1 \% \mathrm{SDS}, 60^{\circ} \mathrm{C} \times 60 \mathrm{~min}$ ). For RNA probe synthesis, renin cDNA cloned in pGEM-4 plasmid was linearized and uniformly ${ }^{32} \mathrm{P}$-labeled single-stranded antisense cRNA ( $\sim 10^{9} \mathrm{cpm} / \mu \mathrm{g}$ probe) was transcribed with T7 RNA polymerase and purified with G-50 Sephadex RNA columns. Riboprobes were hybridized to RNA blots as described above except hybridization temperature was $50^{\circ} \mathrm{C}$ and nylon membranes were washed at higher stringency $(2 \times$ $\mathrm{SSC}, 0.1 \% \mathrm{SDS}, 22^{\circ} \mathrm{C} \times 15 \mathrm{~min} ; 0.1 \times \mathrm{SSC}, 1 \% \mathrm{SDS}, 65^{\circ} \mathrm{C} \times 60 \mathrm{~min}$; $0.1 \times \mathrm{SSC}, 1 \% \mathrm{SDS}, 75^{\circ} \mathrm{C} \times 60 \mathrm{~min}$ ). Labeled transcripts were identified by autoradiography.

In vivo rat studies and isolated nonperfused tubules and blood vessels. Pathogen-free 90-120-g Sprague-Dawley rats (Harlan Sprague Dawley, Inc., Houston, TX) were used for studies with isolated glomeruli and microdissected tubule and vascular segments. Animals were fed regular rat chow and allowed to drink water ad lib. Some of the rats were treated with the angiotensin-converting-enzyme inhibitor enalapril ( $200 \mathrm{mg} /$ liter of drinking water) for 5-6 d. Control and enalapriltreated rats drank the same amount of water and gained similar amounts of weight throughout the study. Animals were then anesthetized, plasma was collected, and specific vascular and nephron segments were dissected as previously described (30). Briefly, rat kidneys were perfused with $1 \mathrm{mg} / \mathrm{ml}$ collagenase and $0.05 \%$ BSA and cortical slices were digested with collagenase for $40 \mathrm{~min}$ at $37^{\circ} \mathrm{C}$ in a Hepes-buffered solution with the following composition: $(\mathrm{mM}) 125 \mathrm{NaCl}, 5 \mathrm{KCl}$, $3 \mathrm{NaAcetate}, 2 \mathrm{CaCl}_{2}, 1.2 \mathrm{MgSO}_{4}, 1 \mathrm{NaH}_{2} \mathrm{PO}_{4}, 5.5$ glucose, 6 L-alanine, 1 L-glutamine, and 5 Hepes; $\mathrm{pH} 7.4$ ). Specific segments were dissected at $15^{\circ} \mathrm{C}$ and tubule lengths were measured with a calibrated eyepiece micrometer.

Detection of renin $m R N A$ in renal tubules and blood vessels. For mRNA detection, we used the reverse transcriptase-polymerase chain reaction (RT-PCR) technique of Moriyama et al. (31). Specific tubule segments $(5 \mathrm{~mm})$ or blood vessels $(2 \mathrm{~mm})$ were microdissected, rinsed, attached to glass beads, and transferred to a reaction tube. The segments were rinsed four times with ice-cold dissection solution containing RNAsin ( $1 \mathrm{U} / \mu \mathrm{l}$; Promega Corp., Madison, WI), and then permeabilized with $2 \%$ Triton X-100 in the presence of RNasin. cDNA synthesis was carried out in the presence of $200 \mathrm{U}$ MMLV reverse transcriptase (Bethesda Research Laboratories, Gaithersburg, MD), 5 $\mu \mathrm{M}$ oligo-dT ${ }_{16}, 1 \mathrm{mM} \mathrm{dNTPs,} \mathrm{and} 3 \mathrm{mM} \mathrm{Mg}^{2+}$. In some tubes, reverse transcriptase was omitted to control for contamination or amplifica- tion from renin DNA. The temperature profile was annealing at room temperature for $5 \mathrm{~min}$, extension at $42^{\circ} \mathrm{C}$ for $60 \mathrm{~min}$, and termination at $99^{\circ} \mathrm{C}$ for $5 \mathrm{~min}$. PCR was performed on segment-specific cDNA using specific oligonucleotide primers ( sense primer, 5 '-TGCCACCTTGTTGTGTGAGG-3'; reverse primer, 5'-ACCCGATGCGATTGTTATGCCG-3'). PCR reactions contained $4 \mu \mathrm{M}$ primers, $4 \mathrm{mM} \mathrm{Mg}^{2+}$, $200 \mu \mathrm{M}$ dNTPs, reaction buffer, and cDNA in a $98-\mu \mathrm{l}$ reaction volume. To minimize non-specific amplification, we used a hot start procedure whereby PCR samples were placed in a thermocycler (Perkin-Elmer Cetus Instruments, Norwalk, CT) prewarmed to $94^{\circ} \mathrm{C}$. After $2 \mathrm{~min}, 2.5$ $\mathrm{U}$ of Taq DNA polymerase (Promega Corp.) was added to the reaction tubes. The PCR amplification consisted of 35 cycles of $94^{\circ} \mathrm{C}$ for $30 \mathrm{~s}$ (denaturation), $58^{\circ} \mathrm{C}$ for $1 \mathrm{~min}$ (annealing), and $72^{\circ} \mathrm{C}$ for $1.25 \mathrm{~min}$ (extension), followed by an additional $5 \mathrm{~min}$ final extension at $72^{\circ} \mathrm{C}$. The PCR reaction products were size fractionated by agarose gel electrophoresis, transferred to nylon filters, and probed with a ${ }^{32} \mathrm{P}$-endlabeled internal oligonucleotide (5'-GGACCTACACTCTCAGCAACATGGA- $\left.3^{\prime}\right)$. The prehybridization, hybridization, and washing conditions were similar to those of Garcia-Perez et al. (32), except the final wash was with $0.5 \times$ SSC and $0.1 \%$ SDS. We optimized the primer location, primer concentration, $\mathrm{Mg}^{2+}$, and annealing temperature to produce the greatest amount of a single PCR product. PCR primers were shown to be in separate exons by the absence of PCR product of the predicted size either in lanes lacking reverse transcriptase (see Figs. 4 and 5) or in tubes containing $1 \mu \mathrm{g}$ per tube of rat genomic DNA (data not shown). The primer sets produced a single band of the predicted size ( $374 \mathrm{bp}$ ) on ethidium bromide-stained agarose gels.

\section{Results}

Renin activity in cultured proximal tubule cells: isoproterenol and forskolin increase renin content but not renin release. We first examined whether cellular renin is secreted from proximal tubule cells in primary culture. Renin activity was detected in the supernatant of proximal tubule cells (Fig. 1). However, renin activity is low in proximal tubule cells compared with supernatant from primary culture of JG cells, which typically expresses renin activity of $200-300 \mathrm{ng} \mathrm{AI} / \mathrm{h}$ per mg. Since both isoproterenol and forskolin increase renin secretion in JG cells in culture, we examined whether a similar stimulation occurred in proximal tubule cells in culture. As shown in Fig. 1, neither agent had a significant effect on renin secreted from proximal tubule cells in culture. Fig. 2 shows the results of renin content in proximal tubule cells. Renin activity was de-

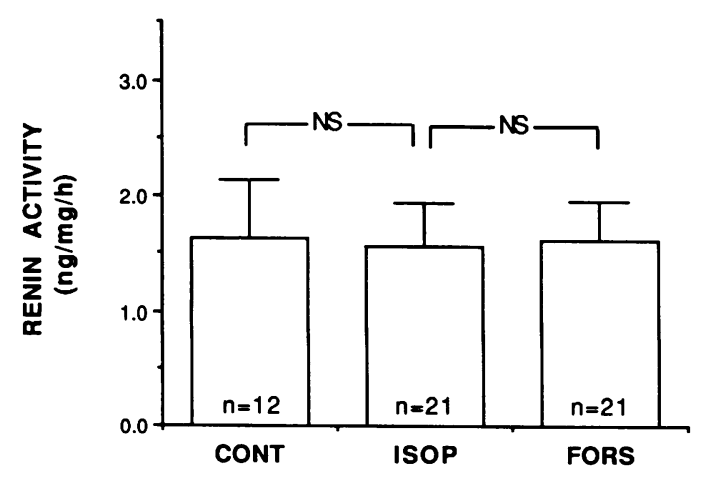

Figure 1. Renin secretion was measured as renin activity in the cell culture medium. Confluent proximal tubule cells were treated with either control medium (con), medium containing $10^{-5} \mathrm{M}$ isoproterenol ( isop), or $10^{-5}$ forskolin (fors). Results are shown as mean \pm SE. $n$, number of experiments. Statistical significance was assessed by Scheffe's two-way analysis of variance. 


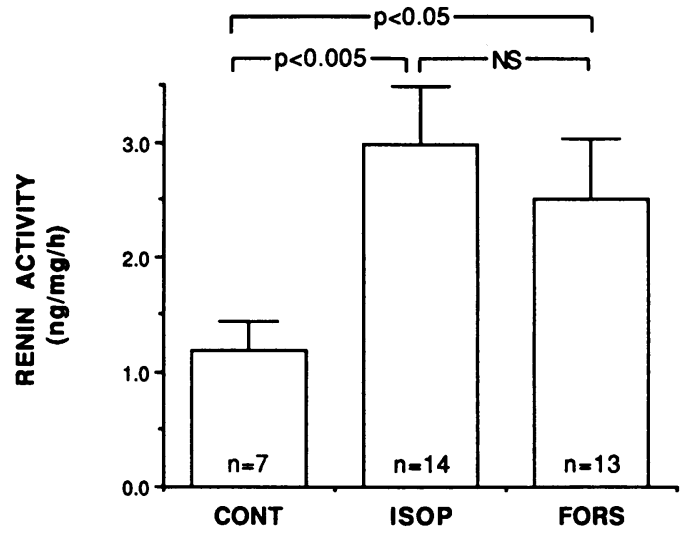

Figure 2. Renin content was measured as renin activity in proximal tubule cell lysate. Cells were incubated with either control medium (con), medium containing $10^{-5} \mathrm{M}$ isoproterenol (isop), or $10^{-5}$ forskolin (fors) before cell lysis. Results are shown as mean \pm SE. $n$, number of experiments. Statistical significance was assessed by Scheffe's two-way analysis of variance.

tected in cell lysates and incubation with $10^{-5} \mathrm{M}$ isoproterenol or $10^{-5} \mathrm{M}$ forskolin increased renin content by 150 and $110 \%$, respectively.

To confirm that the renin activity detected is due to renin rather than other renin-like peptidases, we studied the effects of the nonpeptide renin inhibitor A-74273 on cellular renin activity. Proximal tubule cells were incubated with $10^{-5} \mathrm{M}$ isoproterenol in the presence or absence of $10^{-5} \mathrm{M} \mathrm{A}-74273$ and renin content was measured. Renin content was reduced by $60 \%$ in the presence of the inhibitor (without inhibitor, $3.60 \pm 0.47 \mathrm{ng} / \mathrm{mg}$ per $\mathrm{h}$; with inhibitor, $1.47 \pm 0.47 \mathrm{ng} / \mathrm{mg}$ per $\mathrm{h} ; n=4, P<0.05, t$ test $)$. These results suggest that $\beta$-adrenergic or adenylyl cyclase stimulation increases renin synthesis but not secretion by proximal tubule cells in culture.

Expression of renin $m R N A$ in cultured proximal tubule cells. To further confirm that renin activity detected in the cultured proximal tubule cells is actually due to renin, we examined for expression of renin mRNA in these cells with RNA blots. Fig. 3 depicts a typical experiment. Under stringent conditions, we detected a 1.6-kb renin transcript in poly $(\mathrm{A})^{+} \mathrm{RNA}$ from cultured rabbit proximal tubule cells with single-stranded DNA (Fig. 3, lane 3) and RNA (Fig. 3, lane 4) probes. The labeling is unlikely to be due to non-specific hybridization to $18 \mathrm{~s}$ rRNA since there was no labeling in poly $(\mathrm{A})^{-}$RNA (Fig. 3 , lane 2). In agreement with the low levels of renin activity, the renin transcript is of low abundance in the proximal tubule. Although we detected renin transcript with single-stranded probes, we were not able to detect renin mRNA using random hexamer-primed double-stranded probes labeled to specific activities of $1 \times 10^{9} \mathrm{cpm} / \mu \mathrm{g}$ (data not shown). Comparison with total cellular RNA from JG cells (Fig. 3, lane 1) allows an approximate quantitation of the abundance of renin transcript in proximal tubule cells. Assuming poly $(\mathrm{A})^{+} \mathrm{RNA}$ constitutes $\sim 3 \%$ of mammalian cellular RNA, the renin mRNA abundance of proximal tubule cells is $\sim 2-3 \%$ of that in JG cells.

With this low level of renin activity and transcript, one can question the possibility of contaminating JG cells in the primary culture giving rise to false-positive results. We therefore examined whether JG cells could thrive under proximal tubule culture conditions. JG cells were harvested from rat cortex us-

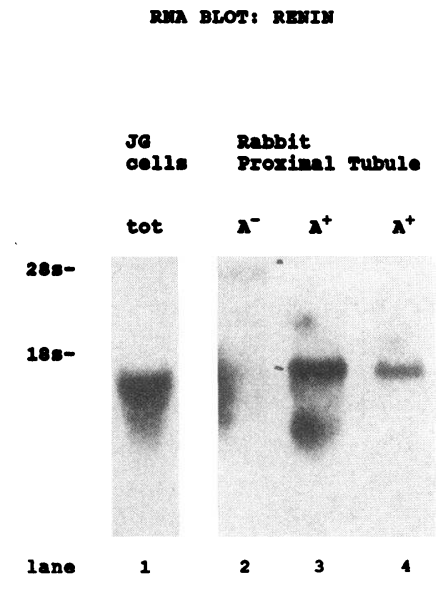

Figure 3. RNA blots were performed as described in text. Lane 1 shows labeling of renin transcript in $10 \mu \mathrm{g}$ of total cellular RNA from freshly isolated rat JG cells. Lane 2 is a negative control containing 10 $\mu \mathrm{g}$ of $\operatorname{poly}(\mathrm{A})^{-}$RNA from proximal tubule cells. Lane 3 shows labeling of $\mathrm{a} \sim 1.6 \mathrm{-kb}$ message by a single-stranded renin cDNA probe on $10 \mu \mathrm{g}$ of $\operatorname{poly}(\mathrm{A})^{+}$RNA from cultured proximal tubule cells. Lanes 1-3 were exposed for 52 h. Lane 4 shows labeling of a similar size transcript in $10 \mu \mathrm{g}$ of poly $(\mathrm{A})^{+} \mathrm{RNA}$ from cultured proximal cells with a renin riboprobe. Lane 4 was exposed for $46 \mathrm{~h}$. A total of three independent experiments showed labeling of renin transcript in poly $(A)^{+}$RNA from cultured proximal tubule cells. In one experiment, no specific labeling was demonstrated.

ing methods previously described (24) and maintained in either serum-free proximal tubule culture medium or serumcontaining ( $2 \%$ FBS) JG cell medium (24) in parallel for $2 \mathrm{wk}$. JG cells kept in serum-free proximal tubule culture medium contained no detectable renin activity at both 7 and $14 \mathrm{~d}$ in culture, whereas JG cells maintained in JG cell medium ( $2 \%$ FBS) exhibited both secreted and cellular renin activity at both 7 and $14 \mathrm{~d}$ in culture (mean \pm SE in $\mathrm{ng} / \mathrm{mg}$ per $\mathrm{h}$ : secreted renin, $280.3 \pm 51.5$ at $7 \mathrm{~d}, 259.2 \pm 52.5$ at $14 \mathrm{~d}$; cellular renin, $292 \pm 53.1$ at 14 d).

Regulated expression of renin $M R N A$ by $R T-P C R$ in rat kidney microdissected structures. We have shown in cell culture that proximal tubule cells contain renin transcripts and renin content is regulated by $\beta$-agonists. Although there is no detectable renin in JG cells grown in proximal tubule medium, it is difficult to absolutely exclude the possibility of very small amounts of JG cells in the proximal tubule culture. To document renin expression in a proximal tubule sample that is unequivocally free of contamination from other renin-expressing tissues, we examined for the presence of renin mRNA in microdissected proximal tubules in rats using RT-PCR. Fig. 4 shows a typical Southern blot analysis of the RT-PCR amplification products of renin $\mathrm{mRNA}$ in microdissected interlobular artery with attached afferent arteries; S1, S2, and S3 proximal tubules; and glomeruli from normal rats. Renin was easily detectable in the intralobular artery and glomeruli but was absent in S1, S2, and S3 proximal tubules in three independent experiments. Renin was also absent in segments where reverse transcriptase was omitted and in beads lacking tubules processed in parallel, indicating the absence of cross-contamination of tubule and vascular segments by renin DNA sequences.

Since renin mRNA content in the proximal tubule may be bordering on the limit of detectability at baseline conditions, we performed the same study in rats that had been given enalapril, a maneuver that has previously been shown to greatly increase renin immunoreactive protein as well as mRNA in the rat kidney $(33,34)$. After 5-6 d of enalapril treatment, plasma renin activity was considerably higher than in control rats studied in parallel (mean $\pm \mathrm{SE}$ in $\mathrm{ng} \mathrm{AI} / \mathrm{h}$ : enalapril-treated, 1,158 $\pm 57, n=9$; control, 46.3 $\pm 6.4, n=9 ; P<0.001, t$ test $)$. 


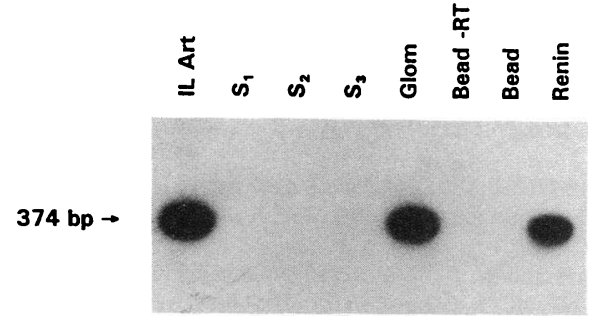

Figure 4. Typical Southern blot of renin RT-PCR products from a control rat. We used $2 \mathrm{~mm}$ of intralobular artery $(I L A)$ and $5 \mathrm{~mm}$ of S1, S2, and S3 proximal tubules. Controls included glass beads without tubules (bead), omission of reverse transcriptase $(-R T)$, glomerulus (glom), and renin cDNA template (renin). Southern blots were processed as indicated in Methods. All the positive PCR products were single bands by ethidium bromide fluorescence (data not shown) and were the expected length of $374 \mathrm{bp}$. Similar results were found in three experiments. In one experiment, renin mRNA was detected in S2.

Similar to plasma renin activity, renin activity in isolated glomeruli was also increased significantly after 5 to $6 \mathrm{~d}$ of enalapril administration (Table I).

We next examined whether renin mRNA is detectable in the proximal tubule under this stimulated state. Fig. 5 shows a typical Southern blot analysis of RT-PCR performed in rats consuming enalapril-containing drinking water. Renin was present in the intralobular artery and glomeruli as in control animals but, in contrast to unstimulated rats, renin mRNA was clearly detected in S2 proximal tubule. In some experiments, renin mRNA was also detected in S1 and S3 but the finding in S2 was consistently seen in every experiment. Under the same conditions, renin mRNA was not detected in medullary thick ascending limb $(5 \mathrm{~mm})$ or $\mathrm{S} 2$ proximal tubule in the absence of reverse transcriptase. Parallel experiments performed on control rats failed to detect renin mRNA in the proximal tubule.

\section{Discussion}

All stimulates proximal tubule $\mathrm{NaCl}$ and $\mathrm{NaHCO}_{3}$ absorption by activation of the apical $\mathrm{Na} / \mathrm{H}$ antiporter $(5,35)$ and basolateral $\mathrm{Na} / 3 \mathrm{HCO}_{3}$ cotransporter (6). The findings of renal arteriovenous increments of AII concentrations and high renal lymphatic levels of AII (36-38) suggest that AII can be generated locally within the kidney. Although the JG apparatus could generate renal AII, the finding of high AII levels along the entire proximal convoluted tubule in an in vivo micropuncture study suggests that one of the sites of renal AII generation may be the proximal tubule (10). The presence of renin in the proximal tubule would constitute a complete local renin-angiotensin system that is potentially autocrine in action. The coexistence of renin and converting enzyme has been described in JG

Table I. Renin Activity in Rat Glomeruli

\begin{tabular}{lrr}
\hline & Control & \multicolumn{1}{c}{ Enalapril } \\
\hline Supernatant & $138 \pm 60$ & $306 \pm 227^{*}$ \\
Cellular lysate & $51 \pm 16$ & $1437 \pm 165^{*}$
\end{tabular}

Mean \pm SE, $n=3 .^{*} P<0.05$ enalapril vs. control, $t$ test.

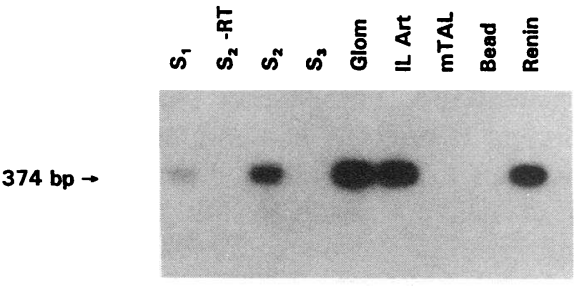

Figure 5. Typical Southern blot of renin RT-PCR products from a rat drinking enalapril for $5 \mathrm{~d}$. Segment lengths and controls are as described in Fig. 4. In addition, we used $5 \mathrm{~mm}$ medullary thick ascending limb $(m T A L)$ as a negative control. All the positive PCR products were single bands by ethidium bromide fluorescence (data not shown) and were the expected length of $374 \mathrm{bp}$. Similar results were found in four experiments.

cells (39), endothelial cells (40), and certain neural and adrenal cell lines $(41,42)$; angiotensinogen is also present in neuroblastoma cells (43).

It has been difficult to document renin synthesis in the proximal tubule because immunohistochemical detection of renin is compatible with either synthesized renin or filtered renin absorbed from the tubule lumen. Since endocytosed renin is unlikely to persist in the proximal tubule after $2 \mathrm{wk}$ in culture, any renin present in cultured proximal tubule cells is probably synthesized endogenously. In addition, the finding of regulation by isoproterenol and forskolin and mRNA expression in cultured proximal tubule cells further argues against trapped renin from glomerular filtrate. Lastly, regulated expression of renin mRNA in the $\mathrm{S} 2$ segment proves that renin in the proximal tubule is not derived solely from glomerular filtrate.

In situ hybridization studies have failed to detect renin transcript in the proximal tubule (19-21). One possible explanation for this is a very low level of renin message in this nephron segment. We too were unable to detect renin mRNA in microdissected tubules with RT-PCR under baseline conditions in three out of four experiments. In one experiment, renin mRNA was detected in S2 under baseline conditions. In some of these studies, when we performed second stage PCR on the first stage PCR amplification products, we detected appropriate size bands that hybridized to an internal renin oligonucleotide whereas the reactions lacking $\mathrm{RT}$ remained negative even with second stage PCR (data not shown). The significance of these positive findings is unclear, though it may reflect extremely low levels of renin transcript in the proximal tubule under baseline conditions. However, when we stimulated renin expression with converting enzyme inhibition, we easily detected renin mRNA in S2. Likewise, in cultured proximal tubule cells renin mRNA is also of low abundance. This very low transcript level in cultured proximal tubule cells parallels the low renin activity. However, unlike JG cells, which secrete renin to the systemic circulation, the low level of renin production in the proximal tubule may be sufficient for an autocrine system. In addition, at the level of the whole renal cortex, the number of proximal tubule cells far exceeds that of JG cells. Therefore, the amount of renin produced by proximal tubule cells may actually contribute significantly to total renin production.

It is highly unlikely that the low level of renin activity and transcript level in the cultured proximal tubule cells is due to 
JG cell contamination for several reasons. First, proximal tubule cells are harvested in the F4 fraction (density, 1.21-1.23 $\mathrm{g} / \mathrm{ml})(23)$ in the proximal tubule preparation (see Methods) whereas JG cells sediment at a density of $1.06 \mathrm{~g} / \mathrm{ml}(25,44)$, which places them in the F1 fraction in the Percoll gradient. Second, even if some JG cells cofractionate with proximal tubules, JG cells are unlikely to survive under the present culture conditions because serum is required to maintain adult rat JG cells in primary culture $(25,44)$. When we cultured JG cells in proximal tubule medium and JG cells medium in parallel, no renin activity was detected in JG cells grown in proximal tubule medium, whereas JG cells kept in JG cell medium continued to express renin. Lastly, the demonstration of renin mRNA in microdissected proximal tubules rules out contamination as a cause of the positive results.

Yanagawa and co-workers (45) recently reported a timedependent increase in renin activity in the supernatant of cultured rabbit proximal tubule cells. In our studies, we tested the effects of $\beta$-agonist on renin activity in the supernatant of proximal tubule cells. Our findings suggest that renin is secreted from the proximal tubule in a constitutive rather than an agonist-stimulated fashion. Although it is possible that mechanisms of regulated secretion are lost in the process of primary culture, an alternative explanation is that renin may act primarily intracellularly, cleaving angiotensinogen in an intracellular compartment.

Cellular renin content was increased by both isoproterenol and forskolin and proximal tubule renin mRNA expression is enhanced by in vivo angiotensin-converting-enzyme inhibition. The significance of this regulation is not presently clear. In salt depletion, angiotensinogen, renin, AII, and AII receptors are all increased in the kidney $(7,46,47)$. The upregulation of angiotensinogen mRNA has been localized to the proximal tubule (46) but it is not known whether proximal tubule renin is increased with salt depletion. On the basis of our findings of increased renin synthesis with isoproterenol, one can speculate that proximal tubule renin may also be upregulated in salt depletion via $\beta$-adrenergic stimulation. The stimulation of the proximal tubule renin-angiotensin system by $\beta$-agonists can also contribute to the stimulation of proximal tubule volume absorption by $\beta$-agonists $(48,49)$ and the activation of $\mathrm{Na} / \mathrm{H}$ antiporter seen in salt restriction (50).

\section{Acknowledgments}

The authors acknowledge the technical assistance of Elizabeth McAllister, Martha Ferguson, Audrey Eskew, and Matthew Carr. We are grateful to Dr. David Russell for his helpful advice and discussions.

The above work was supported by the Research Service of the Veterans Administration; National Institutes of Health grants DK39298, DK01888, and DK41726; and American Heart Association Texas Affiliate grant $91 \mathrm{G} 096$. J. Widell was supported by National Institutes of Health training grant T32DK0730713.

\section{References}

1. Liu, F.-Y., and M. G. Cogan. 1987. Angiotensin II: a potent regulator of acidification in the rat early proximal convoluted tubule. J. Clin. Invest. 80:272275.

2. Liu, F.-Y., and M. G. Cogan. 1988. Angiotensin II stimulation of hydrogen ion secretion in the rat early proximal tubule: modes of action, mechanisms, and kinetics. J. Clin. Invest. 82:601-607.
3. Harris, P. J., and J. A. Young. 1977. Dose-dependent stimulation and inhibition of proximal tubule sodium reabsorption by angiotensin II in the rat kidney. Pfluegers Arch. Eur. J. Physiol. 367:295-297.

4. Schuster, V. L., J. P. Kokko, and H. R. Jacobson. 1984. Angiotensin Il directly stimulates sodium transport in rabbit proximal convoluted tubules. $J$. Clin. Invest. 73:507-515.

5. Saccomani, G., K. D. Mitchell, and L. G. Navar. Angiotensin II stimulation of $\mathrm{Na} / \mathrm{H}$ exchange in proximal tubule cells. 1990. Am. J. Physiol. 258:F1188F1195.

6. Geibel, J., G. Geibisch, and W. F. Boron. 1990. Angiotensin II stimulates both $\mathrm{Na} / \mathrm{H}$ exchange and $\mathrm{Na} / \mathrm{HCO}_{3}$ cotransport in the rabbit proximal tubule. Proc. Natl. Acad. Sci. USA. 87:7917-7920.

7. Douglas, J. G. 1987. Angiotensin receptor subtypes of the kidney cortex. Am. J. Physiol. 22:F1-F7.

8. Brown, G. P., and J. G. Douglas. 1982. Angiotensin II binding sites on isolated rat brush border membranes. Endocrinology. 111:1830-1836.

9. Brown, G. P., and J. G. Douglas. 1983. Angiotensin II binding sites on rat and primate isolated renal tubular basolateral membranes. Endocrinology. 112:2007-2014.

10. Seikaly, M. G., B. S. Arant, and F. D. Seney. 1990. Endogenous angiotensin concentrations in specific intrarenal fluid compartments of the rat. J. Clin. Invest. 86:1352-1357.

11. Richoux, J. P., J. L. Cordonnier, J. Bouhnik, E. Clausen, P. Corvol, J. Menard, and G. Grignon. 1983. Immunocytochemical localization of angiotensinogen in rat liver and kidney. Cell Tissue Res. 233:439-451.

12. Ingelfinger, J. R., W. M. Zuo, E. A. Fon, K. E. Ellison, and V. J. Dzau. 1990. In situ hybridization evidence for angiotensinogen $m R N A$ in the rat proximal tubule. J. Clin. Invest. 85:417-423.

13. Campbell, D. J., and J. H. Habener. 1987. Regional distribution of angiotensinogen messenger RNA in rat adrenal and kidney. J. Hypertens. 4:S385S387.

14. Ward, P. E., E. G. Erdos, C. D. Gedney, R. B. Dowben, and R. C. Reynolds. 1976. Isolation of membrane bound renal enzyme that metabolizes kinnins and angiotensin. Biochem. J. 157:543-650.

15. Rix, E. D. Ganten, B. Schull, T. Unger, and R. Taugner. 1981. Converting-enzyme in the choroid plexus, brain, and kidney: immunocytochemical and biochemical studies in rats. Neurosci. Lett. 22:125-130.

16. Marchetti, J., S. Rouseau, F. Alhenc-Gelas. 1987. Angiotensin I converting enzyme and kinin-hydrolyzing enzyme along the rabbit nephron. Kidney Int. 31:744-751.

17. Brunval, P., N. Hinglais, F. Alhenc-Gelas, V. Tricotte, P. Corrol, J. Menard, J. P. Camilleri, and J. Bariety. 1986. Angiotensin I converting enzyme in human intestine and kidney. Ultrastructural immunohistochemical localization. Histochemistry. 85:73-80.

18. Taugner, R., E. Hackenthal, E. Rix, R. Nobling, and K. Poulsen. 1986. Immunocytochemistry of the renin-angiotensin system: renin, angiotensinogen, angiotensin I, angiotensin II, and converting enzyme in the kidneys of mice, rats, and tree shrews. Kidney Int. 22(Suppl.):S33-S43.

19. Deschepper, C. F., S. H. Mellon, F. Cumin, J. D. Baxter, and W. F. Ganong. 1986. Analysis by immunocytochemistry and in situ hybridization of renin and its mRNA in kidney, testis, adrenal, and pituitary of the rat. Proc. Natl. Acad. Sci. USA. 83:7552-7556.

20. Gomez, R. A., K. R. Lynch, B. C. Sturgill, J. P. Elwood, R. L. Chevalier, R. M. Carey, and M. J. Peach. 1989. Distribution of renin mRNA and its protein in the developing kidney. Am. J. Physiol. 257:F850-F858.

21. Dzau, V. J., K. E. Ellison, T. Brody, J. Ingelfinger, and R. E. Pratt. 1987. A comparative study of the distribution of renin and angiotensinogen messenger ribonucleic acids in rat and mouse tissues. Endocrinology. 120:2334-2338.

22. Horie, S., O. Moe, A. Tejedor, and R. J. Alpern. 1990. Preincubation in acid medium increases $\mathrm{Na} / \mathrm{H}$ antiporter activity in cultured renal proximal tubule cells. Proc. Natl. Acad. Sci. USA. 87:4742-4745.

23. Vinay, P., A. Gougoux, and G. Lemieux. 1981. Isolation of a pure suspension of rat proximal tubules. Am. J. Physiol. 10:F403-F411.

24. Henrich, W. L., E. A. McAllister, P. B. Smith, and W. B. Campbell. 1988 Guanine 3',5'-cyclic monophosphate as a mediator of inhibition of renin release. Am. J. Physiol. 24:F474-F478.

25. Poulsen, K., and K. Jorgensen. 1974. An easy radioimmunological microassay of renin activity, concentration, and substrate in human and animal plasma and tissues based on angiotensin I trapping by antibody. J. Clin. Endocrinol. Metab. 39:816-819.

26. Lowry, O. H., N. J. Rosenbrough, A. L. Farr, and R. J. Randall. 1951. Protein measurement with Folin phenol reagent. J. Biol. Chem. 193:265-275.

27. Scheffe, H. The Analysis of Variance. Wiley, New York. 1959.

28. Moe, O. W., R. T. Miller, S. Horie, A. Cano, P. A. Preisig, and R. J. Alpern. 1991. Differential regulation of $\mathrm{Na} / \mathrm{H}$ antiproter by acid in renal epithelial cells and fibroblasts. J. Clin. Invest. 88:1703-1708.

29. Burnham, C. E., C. L. Hawelu-Johnson, B. M. Frank, and K. R. Lynch. 1987. Molecular cloning of rat renin cDNA and its gene. Proc. Natl. Acad. Sci. USA. 84:5605-5609. 
30. Star, R. A., N. Nonoguchi, R. Balaban, and M. A. Knepper. 1988. Calcium and cyclic adenosine monophosphate as second messengers in the rat inner medullary collecting duct. J. Clin. Invest. 81:1879-1888.

31. Moriyama, T., H. R. Murphy, B. M. Martin, and A. Garcia-Perez. 1990. Detection of specific mRNAs in single nephron segments by use of the polymerase chain reaction. Am. J. Physiol. 258:F1470-F1474.

32. Garcia-Perez, A., H. R. Murphy, B. M. Martin, S. Uchida, H. Murer, B. D. Cowley, Jr., J. S. Handler, and M. B. Burg. 1989. Molecular cloning for cDNA coding for aldose reductase: regulation of specific mRNA accumulation by $\mathrm{NaCl}-$ mediated osmotic stress. J. Biol. Chem. 264:16821-16825.

33. Gomez, R. A., K. R. Lynch, R. L. Chevalier, A. D. Everett, D. W. Jones, N. Wilfong, M. J. Peach, and R. M. Carey. 1988. Renin and angiotensinogen gene expression and intrarenal renin distribution during ACE inhibition. Am. J. Physiol. 254:F900-F906.

34. Gomez, R. A., R. L. Chevalier, A. D. Everett, J. P. Elwood, M. J. Peach, K. R. Lynch, and R. M. Carey. 1990. Recruitment of renin gene-expressing cells in adult rat kidney. Am. J. Physiol. 259, 28:F660-F665.

35. Cano, A., P. A. Preisig, R. T. Miller, and R. J. Alpern. 1991. Angiotensin II regulates $\mathrm{Na} / \mathrm{H}$ antiporter activity in OKP cells. J. Am. Soc. Nephrology. 2:450. (Abstr.)

36. Bailie, M. D., F. C. Rector, Jr., and D. W. Seldin. 1971. Angiotensin II in arterial and renal venous plasma and renal lymph in the dog. J. Clin. Invest. 50:119-126.

37. Proud, D., S. Nakamura, F. A. Carone, M. Herring, M. Kawamura, T. Inagami, and J. J. Pisano. 1984. The kallikrein-kinin and renin-angiotensin system in rat renal lymph. Kidney Int. 24:880-885.

38. Rosivall, L., A. J. Narkates, S. Oparil, and L. G. Navar. 1987. De novo intrarenal formation of angiotensin II during control and enhanced renin secretion. Am. J. Physiol. 252:F1118-F1123.

39. Rightsel, W. A., T. Okamura, T. Inagami, J. A. Pitcock, Y. Takii, B. Brooks, P. Brown, and E. E. Muirhead. 1982. Juxtaglomerular cells grown as monolayer cell culture contain renin, angiotensin I converting enzyme, angiotensins I, II, and III. Circ. Res. 50:822-829.
40. Kifor, I., and V. J. Dzau. 1987. Endothelial renin-angiotensin pathway: evidence for intracellular synthesis and secretion of angiotensin. Circ. Res. $60: 422-428$.

41. Okamura, T., D. L. Clemens, and T. Inagami. 1981. Renin, angiotensins, and angiotensinogen converting enzyme in neuroblastoma cells: evidence for intracellular formation of angiotensin. Proc. Natl. Acad. Sci. USA. 78:69406943.

42. Naruse, M., K. Shizume, and T. Inagami. 1984. Renin and angiotensins in the cultured adrenocortical tumor cells of mice. Acta. Endocrinol. 108:545-549.

43. Clemens, D. L., E. Clauser, M. R. Celio, and T. Inagami. 1986. Generation of angiotensinogen by cultured neuroblastoma and glioma cells. Brain Res. 364:205-211.

44. Kurtz, A., R. Dellas-Bruna, J. J. Pfeilschifter, R. Taugner, and C. Bauer. 1986. Atrial natriuretic peptide inhibits renin release from juxtaglomerular cells by a cGMP-mediated process. 1986. Proc. Natl. Acad. Sci. USA. 83:4769-4773.

45. Yanagawa, N., A. W. Capparelli, O. D. Jo, A. Friedal, J. D. Barrett, and P. Eggena. 1991. Production of angiotensinogen and renin-like activity by rabbit proximal tubular cells in culture. Kidney Int. 39:938-941.

46. Ingelfinger, J. R., R. E. Pratt, K. E. Ellison, and V. J. Dzau. 1986. Sodium regulation of angiotensinogen mRNA expression in rat kidney cortex and medulla. J. Clin. Invest. 78:1311-1315.

47. Steiner, R. W., B. J. Tucker, and R. C. Blantz. 1979. Glomerular hemodynamics in rats with chronic sodium depletion, effect of saralasin. J. Clin. Invest. 64:503-512.

48. Bello-Reuss, E. 1980. Effect of catecholamines on fluid reabsorption by the isolated proximal convoluted tubule. Am. J. Physiol. 238:F347-F352.

49. Weinman, E. J., S. C. Sansom, T. F. Knight, and H. O. Senekjian. 1982. Alpha and beta adrenergic agonists stimulate water absorption in the rat proximal tubule. J. Membr. Biol. 69:107-111.

50. Moe, O. W., A. Tejedor, M. Levi, D. W. Seldin, P. A. Preisig, and R. J. Alpern. 1991. Dietary $\mathrm{NaCl}$ modulates $\mathrm{Na} / \mathrm{H}$ antiporter activity in renal cortical apical membrane vesicles. Am. J. Physiol. 29:F130-F137. 